\title{
Livelihood Diversification Strategies and Livelihood Outcome of Rural Household in Ethiopia: A Reviewed Paper
}

\author{
Fami Abdurezak Sherifa \\ Department of Agricultural Economics, College of Agriculture and Natural Resource, Bonga University, \\ P O Box: 334, Kafa, Ethiopia
}

\begin{abstract}
This review was carried out on appraisal of rural household in livelihood diversification strategies and livelihood outcome in Ethiopia. The target is specifically to review the impact of income diversification on livelihood outcome situation, to review determinant participation of rural household in off/non-farm diversification, and to review the determinants level of income generated from the activities in Ethiopia. In Ethiopia, Agriculture is the main livelihood of most population in the countries and it contributes $79 \%$ of foreign earnings, employs some $79 \%$ of the population and $34.1 \%$ to the GDP and is the major sources of raw material and capital for investment and market. Despite it's the main contribution for the event of country's economy, the prevailing capacity of agriculture to achieve food and livelihood security is tremendously declining from time to time due to diverse challenges and risks. As a result, majority of the population is multidimensional poor, affected by some combination of food insecurity, insufficient access to adequate education and health services and inadequate employment opportunities. With this reason Ethiopia faces high levels of food insecurity and ranking joined of the hungriest countries within world even if the Global Hunger Index (GHI) score has declined from 55.9 in 2000 to 29.1 in 2018. As reading from different literature, income diversification is coined for these situations to handle all the interrelated problems associated to economy of rural household. As a result, a numbers of rural household participate in off/non-farm activities additionally to on-farm have gradually customized as coping mechanism and to boost their livelihood. Therefore, policy makers should give due emphasis to the aforementioned variables within the empirical review that determine participation of rural household in income diversification activities so as to improve the livelihood of smallholder farmers.
\end{abstract}

Keywords: Rural household, livelihood diversification strategies and livelihood outcome

DOI: $10.7176 / \mathrm{JAAS} / 74-02$

Publication date:July $31^{\text {st }} 2021$

\section{Introduction}

Ethiopia is an agriculture dependent country with a complete population of around 113.56 millions. The foremost source of livelihood of the people of Ethiopia is agriculture. It contributes $79 \%$ of foreign earnings, employs some $79 \%$ of the population and $34.1 \%$ to the GDP and is that the major sources of raw material and capital for investment and market [1]. Despite it's the most contribution for the event of country's economy, the present capacity of agriculture to achieve food and livelihood security is enormously declining from time to time because of diverse challenges and risks. As a result, eighty-seven percent of the population is multidimensional poor suffering from some combination of food insecurity, insufficient access to adequate education and health services and inadequate employment opportunities [2] due to the sector is dominated by subsistence farming system $[3,4,5]$. Smallholder farming system during which less than one hectare of landowner accounts for quite 90 percent of the agricultural production and for about 95 percent of the entire area under crop production [6]. Thus, agricultural product by this farming system couldn't meet their food requirements due to the imbalance between the population growth rate and the agricultural production and productivity in Ethiopia. Highly population growth within the country reduces landholding size rapidly and creates high level of unemployment in rural areas $[7,8,9)$. As a result, smallholder farmers in Ethiopia have been stressed to possess a precarious livelihood [10].

Other factors responsible for declining Agricultural productivity are climate change, pest, deceases, erratic rainfall, or other shocks. Among these factors, livelihoods of most African people have been threatened by climate risks [11]. For instance, it's estimated that rain-fed crop yields could possibly fall by $50 \%$ by 2020 and net crop revenues could drop in $90 \%$ [12]. Consistent with the global Climate Change Vulnerability Index, Ethiopia is ranked seventh among countries at risk from the impacts of climate change [3]. Hence, Ethiopia faces high levels of food insecurity and ranking jointly hungriest countries within the world even if the Global Hunger Index (GHI) score has declined from 55.9 in 2000 to 29.1 in [14].

As a remedy to those problems Ethiopian government gives design policies and strategies in last several years endeavor to enhance the livelihood of the rural population through increasing agricultural productivity in rural areas. However, the role of agricultural productivity in poverty reduction, improving livelihood and enhancing productivity outcomes can't be over emphasized due to this policy gave little attention on livelihood diversification activities. In Ethiopia, the most aim of Millennium Development Goals to attain poverty 
reduction couldn't accomplish yet [15]. The impediment for rural development and agricultures (e.g. Improve income, achieved food security, reduce poverty, increasing agricultural productivity and etc) are lack of sustained and intergenerational commitments to transformation, constitutional and legal constraints, government crowding out the private sector leadership, lack of mechanization options and constrained input supply system, lack of effective and accountable organizational capacity, lack of agricultural and rural financial and credit facilities and environmental degradation in Ethiopia [16]. Hence, there has to be need a mechanism to enhance the livelihood of the rural societies and to overcome the setback linked to rural pecuniary system.

As demonstrated within different literature the term income diversification is coined for these situations to handle all the interrelated problems cited above. In developing country, diversification to nonfarm livelihood strategies instead of relying only on subsistence farming facilitates household to own stability income, creating job opportunities for unemployment and reduce poverty [17,18], reduce rural-urban migration [19] and to raised address environmental stresses in developing country [20, 21, 22]. Similarly, in Ethiopia, livelihood diversification activities have a good potential role to provide employment and financial sources [23, 8, 24] and encourage sustainable land management practices $[25,26]$ through the choice to allocate labor away from livelihood activities that exploit natural resources to other, less exploitative, livelihood options [26]. Besides it could be addresses climate variability and climate change in Ethiopia according to climate variability and change reported in 2015 in Ethiopia. Within the finding of [23] diversified source of income into nonfarm/off-farm reduces vulnerability to diverse form of shocks, seasonality and trends and provides opportunities for compensate the risks and uncertainties related with agriculture variations.

Empirical studies consistently show the effect of income generating from non-farm and off farm diversification activities on outcome of household livelihood have been conducted in different study area, Ethiopia. Among these studies the impact of livelihood strategies on household food security, agricultural production efficiency, consumption expenditure, poverty and wellbeing are the most notable. In the study of [27] non-farm employment provides additional income that enables farmers to spend more on their basic needs include food, education, clothing and health care. It as well enhances their production and productivity of farming output $[28,29]$. Moreover, diversified livelihood strategies enhance food security and poverty reduction in Ethiopia [15, 30, 31, 32, 33, 34, 35, 36] and attain wellbeing among the rural households [37, 38]. In view of that, the participation rate of rural household in off farm income generating activities has been escalating which was 55\% in 2004 and reached $75 \%$ in 2008 in Ethiopia [24]. [39] finding that 43.9 percent of households were engaged in non-farm activities in 1996 while its average contribution to total household income was very low based on Ministry of Labour and Social Affairs survey from five regions (Amhara, Tigray, Oromiya, South region and the sedentary farming areas of Afar). Moreover, Share of income from rural livelihood diversification activities are increasing substantially in developing country. Across developing countries, around $30 \%$ to $50 \%$ of rural income is generated from non-farm activities [18]; share of non-farm diversified income to total income is around $42 \%$ for Africa, $32 \%$ for Asia, and $40 \%$ for Latin America [40]. As study undertaken by [41] based on Ethiopian Rural Household Survey (ERHS), share of non-farm income was increasing from 16.1 in 1994 to 26.71 in 2009.

However, in Ethiopia there are major barriers for rural household that could hamper households' participation in livelihood diversification which reduces the contribution of off/non-farm activities to total household income. As reviewed in Ethiopia the challenges which affect rural livelihood diversification were lack of capital, poor infrastructures, lack of access to credit service, lack of access to market and marketing service, lack of job opportunities $[42,43]$. Therefore, identifying the factors that determine participation of rural household or smallholder farmers in income diversification activities so as to increase farm household's income, reduce poverty and address food insecurity problems within the country is the main issue for this review paper.

Some review was conducted with context of livelihood diversification in Ethiopia. For instance, [42] carried out a review on "determinants of sustainable rural livelihood diversification of small holder farmers in Ethiopia". And [43] carried out review made on determinants and challenges of rural livelihood diversification in context of country. However, as a country level review made on determinant of income diversification and its impact on household livelihood outcomes is few. Additionally, there were some studies conducted in relation to the topic but it lacks the way of evaluating impact of income diversification on livelihood outcome by using an appropriate econometrics model analysis at the country level. So that the review of the paper tried to compile studies conducted in different part of the country to show real image on contribute knowledge on determinants participation of rural household on income diversification activities and its impact on livelihood outcome. In overall, the aims of the review were to: (1) Review the impact of participation in off/non-farm on household livelihood outcome diversification and (2) Review determinant participation in livelihood diversification (3) Review determinant level of income from off/non-farm activities. In the light of the above, the result generated through review will serve an invaluable intention in informing policy aimed which enrichment the livelihood rural people of Ethiopia. 


\section{Overview of livelihood diversification activities and livelihood outcome 2.1. Basic concepts of livelihood diversification and its definition}

Livelihood embraces the capabilities, assets (including both material and social assets) and activities required for a means of living [44]. According to [45] livelihood could be explained as combinations of the resources utilize and the activities carry out so as to live. In the livelihoods approach, resources are referred to as assets or capitals [46]. Livelihood assets are the resources on which people draw in order to carry out their livelihood strategies [47].

The major livelihood assets are human capital like age, education, gender, health status, household size, dependency ratio and leadership potential [48, 47, 49]; Physical capital comprises the basic infrastructure and producer goods needed to support livelihoods [50]; Social capital which refers to networks and connectedness, Financial capital like savings, credit, and remittances from family members working outside the home [48] and Natural capital is the natural resource stock. Optimizing recourse utilization has need livelihood strategies to maximize profits of rural household and also for coping mechanisms for the poor. According to [50] the term livelihood strategies are defined $a s$ the range and combination of activities and choices that people make in order to achieve their livelihood goals, including productive activities, investment strategies, reproductive choices, etc. Livelihood outcomes are the achievements of livelihood strategies, such as more income, increased well-being and reduced vulnerability, improved food security and a more sustainable use of natural resources [51].

Based on these evidence livelihood strategies is the way of development indicator through maintaining livelihood security, fighting income instability and mitigating risks facing smallholder farmers in developing country. So in this review, livelihood diversification is considered as a means to conceptualize livelihood strategies since it is the process in which rural households create an additionally diverse set of economic activities and assets for their survival and improving the standard of living [52]. Income diversification is an example of livelihood diversification strategies that increases the number of income sources or the balance among the different sources [35]. It includes major portfolio activities consisting on-farm, off-farm and non-farm activities.

Most of the researches carried out in Ethiopia, identified three rural livelihood diversification strategies: on farm, nonfarm and off farm activities $[25,53,35,5,54,55,56]$. However, the main drawback of the studies conducted in rural livelihood diversification strategies in Ethiopia were misunderstanding to differentiate nonfarm activities from off activities and just used interchangeable. According to [57] the most commonly distinctions of on-farm, non-farm and off-farm activities are based on location, sector and function. "Farm" or "agricultural" refers to all activities in the agriculture sector, regardless of location or function. Non-farm includes all activities outside the agricultural sector, regardless of location. On-farm or at-home includes all activities on one's own property, regardless of sectoral or functional classification; almost always selfemployment. Off-farm refers to all activities that can be wage or self-employment aw ay from one's own property not considering of sectoral or functional classification. These definitions has put clearly the classification of work and jobs categorized under each livelihood activity (on farm, off-farm and nonfarm) for other researcher who would like to conduct researches regarding to this topic in the future.

\subsection{Empirical review}

\subsubsection{Determinant participation of rural household in livelihood diversification activities in Ethiopia}

The studies that scrutinize the feature that influencing participation in income diversification activities and level of generated income from the activities used different methodologies and different units of analysis, due to this situation judgment of results complicated at the level of country. Therefore, the determinants of livelihood diversification in each study are reviewed and organized as the subsequent.

[58] Analyzed determinant participation of rural households in non-farm activities using logit model. Household with large number of adult male had high probability of participation in non-farm activities. Household with large number of tropical livestock unit and high level of self sufficiency and cultivated land size and distance to nearest market has negatively relation with probability of participation in non-farm activities.

In study [59] estimates determinant of participation decision in non-farm activities used Multivariate probit. Primary education enhances the probability of engagement in non-farm activities like handicrafts. On the other hand, food-/drink and trade activities do not seem to require formal education, whereas informal education significantly and positively influences the participation in those activities. Higher education appears to be irrelevant for the participation decision into all three types of activities (handcrafts, food/drink and trade). Married heads of household were more likely engaged in food/drink and trade activities than their non-married counterparts (single, divorce, widowed). Households that live closer to market sites are more likely to be engaged in handicraft activities. Closer to all weather road increases probability of households participate in food/drink activities.

[60] examines determinants of income diversification and its share to total household income among rural farm households using cross sectional data collected from South, Nations, Nationalities and People Region, 
Ethiopia; Multinomial logit model was used to identify factors persuade households' choice to participate in various off-farm income diversification sources. In these results, household head participation in off-farm income diversification sources are found to be influenced by sex and age of rural farm household head, education level of household head, family size, number of economically active family members, wealth status farm household head, livestock holding size, size of cultivated land, total household income, asset ownership and type of agro ecologic zone, household head access to credit, membership in farmers' cooperative, experience on agricultural extension service and distance from market center and main road.

The research conducted by [27] analyzed determinant of rural household participation in non-farm activities with using probit model. The variable age has negative effect on participation in nonfarm employments. Family size, possessing a special skill is found to have positive influence on participation in nonfarm employments. Land size, access to irrigation, and distance to the market negatively significant and influences the involvement in nonfarm employments. Variables access to credit and availability of electricity are turned out to be positive as far as the decision to participate in nonfarm employments is concerned.

In the finding of [61] studied determinants participation in non-farm activities using logit model. In this research educational level of the household head, number of pack animals owned, use of family planning, languages spoken by household members and skill training on nonfarm activities have positive and significant effect on rural household's participation in nonfarm activities. On the other hand, sex of headed household, household head's farm experience, operational land holdings, and travel time required to the nearest main market negatively and significantly influence the household's decision to participate in NFA.

Factors affecting participation of rural household in non-farm activities using Multivariate probit model, in North east Ethiopia, Tehuledere District were estimated by [62]; in his study cultivated land, age of household head, sex of head(male) and lowland negatively manipulate partaking of rural households in non-farm activities while farm size, distance to nearest market and education positively influence probability of households participate in nonfarm diversification.

The determinants of participation in non-farm activities using multinomial logit model, in Eastern Ethiopia were identified by [63]. In their study having better education, land holding, access to irrigation and number of adult members are significantly affects decision to participate in nonfarm diversification. Moreover having access to credit, better land size, livestock and number of adults, age, sex of household head, dependency ratio in the household are positively influence the share of income from non farming activities this leads increasing participation of rural household.

Under study of [64] determinants of households' choice and adoption of livelihood diversification strategies were found out by using multinomial logistic regression model for analyzing data from 485 sample respondents. From this result household's level of education, access to credit, income, membership to cooperatives, land size, farm input use were positively significant whereas age, dependency ratio, family size, access to extension services, distance to market, livestock ownership and agro-ecology negatively affect households choice and adoption of livelihood diversification strategies.

In study of [65] factors that influence participation in non-farm activities by using Bivariate probit model, in Humbo District, Southern Ethiopia. According to their finding, land size negatively related with non-farming activities, indicating that small land holding households are more likely to be engaged in non-farm activities in the area. Total TLU was significant for only handicraft activities. Females were more likely to participate in sale of crops, cattle, and food and drink activities. This result reflects traditionally females dominate in sale of crops, cattle, and food and drink activities. Age reflects the younger household head male participation dominates the handicraft non-farm activities. Larger family size household was possibly to delegate the required work load of this activities like purchasing crops, cooking and/or local drink preparation activities to the family's member which supports to engage in non-farm activities of the area. The remaining is an interesting point in which is the effect of education on rural household participation in non-farm activities.

In the finding of [66] analyzed probability of partaking in non-farm diversification activities using logit regression model. The result of their finding years of schooling, farm income is the most imperative factor that encourages farm households' decision to engage into nonfarm activities, But, farm size, member ship in farmers' cooperatives and distance from market center were the most influential factors that negatively enforced households to participate in nonfarm activity.

According to [55] identified the determinants of farmers' participation in income diversification in Wolaita Zone of southern Ethiopia. The Binary logistic regression model was used to analyze farmers' participation in income diversification. In his result education of household head, farm income and participation in local leadership influenced positively and significantly farmers participation in income diversification activities, while the ownership of livestock in tropical livestock unit, sex, total farm size, oxen ownership and market distance negatively and significantly affected the diversification of income.

The livelihood strategies adopted by smallholder farmers and assessed the determinants of their decisions to choose diversified livelihood strategies in Wogera district were identified by [5]. Hence, the determinants 
choosing diversified livelihood strategies were identified by applying multivariate logistic regression for analyzed the collected data. The identified variable, Access to irrigation and credit were positively affected choices of diversified livelihood strategies while being aged, having more farms size and far from the main road hinder the households to diversify the livelihood strategies. The study argues that most of smallholder farmers tend to diversify their livelihood strategies although various factors influence the diversification of livelihood strategies.

As [54] examined the existing livelihood strategies and its determinant via using multinominal logit in Kuarit District, West Gojjam Zone, Amhara Region, Ethiopia. The result from model indicate that access to credit service, total annual income and total family size have positive effect on choices of livelihood diversification strategies while market distance, age, number of livestock holding and dependency ratio have negative effect on decision of livelihood diversification strategies.

The determinants of income diversification among rural households in Soddo District of Gurage Zone, southern Ethiopia were examined by [56]. In his study, multinomial logit model were used for analyzing data and model output illustrate that sex, education, attitude to risk of diversification, family size, size of cultivated land, livestock holding and distances to main road, credit service and market, wealth have statistically significant effects on off-farm employment income while non-farm self employment income was significantly influenced by age, family size, size of cultivated land, cooperative participation, credit service, willingness to diversify income, number of contact by DA's, distance to main road and market, wealth and total crop production in quintal per annual.

According to the study of [67] determinants livelihood diversification practices were identified through applied ordered logit regression model in Hawassa Zuria District of Sidama Zone, Ethiopia. The result from this model showed that education level of household head, land size of household, annual income of household head, membership of households in the organization, credit utilization, and access of extension services were positively significant while age and family size of households were found to be negatively significant in determining the livelihood diversification of households.

\subsubsection{Determinants level of income generated from livelihood diversification activities in Ethiopia}

Within study [68] by using Heckman two-stage model identified the determinants of participation in non-farm activity and level of income from it in the haramaya district east hararghe zone. The results of the empirical analysis show that age of household head, Use of irrigation, Livestock holding, distance from the nearest market, Landholding size affects the level of non-farm income negatively and significantly. Household head attended formal education; non-farm training, household size has positive effect on the probability of participation in nonfarm activity and level of income from non-farm activities.

Assessing [69] the linkage between income diversification and asset ownership among rural households in yayu woreda and hurumu woreda, oromia regional state, Ethiopia; Factors that affect intensity of household income diversification were identified by using Tobit model. Those factors were household asset ownership, aggregate index of human capital, aggregate financial capital index and extension contact were significant and positively affects income diversification while membership in agricultural cooperative, sex of household heads and access to training negatively correlation with income diversification.

The study undertaken by [70] examines the intensity of income diversification and identifying the factors which determine level of income diversification in Asayita woreda in Eastern part of Afar region. The study used multi stage sampling in combination with stratified and simple random sampling procedures to select kebeles and households and the data collected from a sample of 153 rural households. Fractional response regression probit model was employed to determine the level of income diversification among the farm households. The result of the model indicated that male-headed household, education, household size, special skill, electricity, credit utilization and annual household income had statistically significant positive effect on households' level of income diversification where as distance from the market have negative significant effect on it.

The determinants of level of income diversification using censored Tobit model were analyzed by [60]. The level of income diversification are found to be influenced by human capital related variables (sex and age of rural farm household head, education level of household head, family size, number of economically active family members and wealth status farm household head), livelihood assets (livestock holding size, size of total and cultivated land, farm and total household income, asset ownership and type of agro ecologic zone), institution related variables (household head access to credit, membership in farmers' cooperative and experience on agricultural extension service) and infrastructure related variables (distance from market center and main road).

Factors that affect per capita off-farm employment income using two step Heckman selection model were identified by [72]. Households with large farm size, informally educated household heads earn significantly higher income from wage work. Households with older heads, more adult males, more children with five years old or under, higher livestock holding and those who live far from major market earns lower off-farm wage income, in case they participate. As an example, interpretation of the results show that male headed families earn 
higher income from off-farm self employment when compared to female headed household. Number of adult male and children with six to ten years old in the family negatively and significantly relates with the level of per capita self employment income.

As study [28] examined what factors contribute to the income differential, with the evidence from east Hararghe, Oromia, Ethiopia he used linear regression model to identify contributing factors and the model output indicated that, irrigation use, livestock holding, and education level of household head, cultivated area, age and amounts of fertilizer used were the significant variables that contribute to farm income differential in the study area.

[41] examine the determinants of participation in non-farm diversification activities through tobit model and double-hurdle Model were used for determinant level of income diversification in rural Ethiopia by using Ethiopian Rural Household Survey data from 2004-2009. According to him participation in non-farm activity and level of income from it is mainly depends on age of household head, sex, education of household head, household size, dependency ratio, livestock holding, credit, land size, crop income, climate shocks index, death of a working member, illness, access to electricity and distance to nearest town.

The research of [72] investigates the impacts of demographic, economic, and risk factors on participation and intensity of off-farm activities using heckman selection model and panel-Tobit model. The results of the study show that families with high dependency ratio, female household heads, high livestock value, and poor quality of land participated less in off-farm activities. Competition between off-farm and farm activities and effects of seasonality were more apparent from the intensity results than from participation.

In the investigation of [73] estimates determinant share of income from rural non-farm economy using the tobit model. According to their found that having access to credit, better land size, livestock and number of adults in the household significantly and positively influenced the share of income from RNFE. It was also found that age and sex (male) of household head had positive effect on the share of income from RNFE.

[32] Applied multinomial logit and Tobit models on a cross-sectional survey of 120 households and assess that the participation in non-farm activities and the level of returns. Their results show that human capital related variables (gender and age of household head, number of economically active family members, education level of household head and presence of children attending school), livelihood assets (livestock holdings, size of cultivated land), livelihood diversifying strategies (crop based diversification through the number of crops grown and harvested) and infrastructure related variables (proximity to market) influenced participation in non-farm and off farm employment activities and the level of income in the study area.

According to [74] discuss different factors affecting income diversification and assess patterns of income diversification in the Akaki district in Ethiopia using cross-sectional data from 155 farm households using a structured questionnaire and the Tobit model. Their results indicate that family size; number of extension visits per year and education levels had a positive significant effect on income diversification, whereas age of the household head, land size and average distance from the market had a negative and significant influence on income diversification.

Study by [15] identifies the factors that determine the probability of the choices of livelihood strategies using multinomial logit model and for evaluating its impact on livelihood outcome via mean comparison. The Multinomial result indicated that; age of household head, distance from irrigation sources, social status, soil fertility status, education level, distance from DA office, economical active members and soil fertility status, transportation and annual agricultural output were significant variables determining household's choice of livelihood strategies.

\subsubsection{Impact of livelihood diversification activities on livelihood outcome in Ethiopia}

Several empirical studies were conducted on rural livelihood diversification across developing countries, particularly in Ethiopia. Before beginning empirical review, identifying the reason enforces/motivates rural household engaging in livelihood diversification a preliminary issues. There are two core rationale for which rural household diversify their livelihood: push/distress which means survival or coping mechanisms pursued mainly by poor households to address the shocks they are facing [26], Pull/progressive is way to accumulate wealth to find additional income which is mostly regarded as an ex-ante strategy implemented by comparatively rich households [75]. Push factors consist of risk reduction, diminishing returns in land and labour or coping with inefficiency, seasonality, compensating for failures in credit markets or liquidity constraint incomplete or weak financial system, constraints in labor and land markets, lack of support to agricultural prices, Population pressure and climatic uncertainties source, where as pull factors comprise gradual transition to new activities, building on complement arise between activities for instance crop livestock integration, comparative advantage based on the existence of skills, resources and technologies, commercial agriculture, location [20]

Various studies revealed that rural households' participation in livelihood diversification activities exerts a pronounced impact on rural development, agricultural productivity, labor productivity, employment, income, food security, sustainable land management and living standard. [38] Used propensity score matching approach to examine the impact of non-farm work on wellbeing of rural household in eastern hararghe, Ethiopia; they 
revealed that non-farm activity has a positive impact on wellbeing of the households. Similarly, [37] also used propensity score matching approach to examine the impact of non-farm enterprise diversification on households' wellbeing in Ethiopia. The result shows that non-farm enterprise diversification has a positive significant impact on the households' wellbeing. The possible explanation for this is diversification of income sources provides an additional income that enables farmers to spend more on their basic needs include food consumption, education, clothing and health care [27].

In addition to the above studies according to [35], the coefficient of Herfindahl diversification index is positive and significance at 5\% level of significance. In other words, the higher the level of the household income diversification raising food secure of the households. The impact of participation on livelihood diversification on livelihood outcome by using mean comparison that is propensity score matching technique was evaluated by [15]. Thereafter, in their result livelihood diversification has significant effect on livelihood outcome (such as achieving food security and reducing poverty. The finding of [36] was used the second-stage least square (2SLS) regression to assessing the contribution of income diversification on food security in the Ambo district. Their finding showed the positively significant contribution of income diversification to food security which means reduces food insecurity by enhancing households' access to food. Generally, from this result it can be suggested that livelihood strategies are crucial in increasing the households' food security status and reducing poverty levels of farmers which in turn could affect the welfare of the rural farm households.

\subsection{Conceptual Framework for the review}

In order to enhance households' livelihood outcome, major factors must be considered which determine the involvement in livelihood diversification

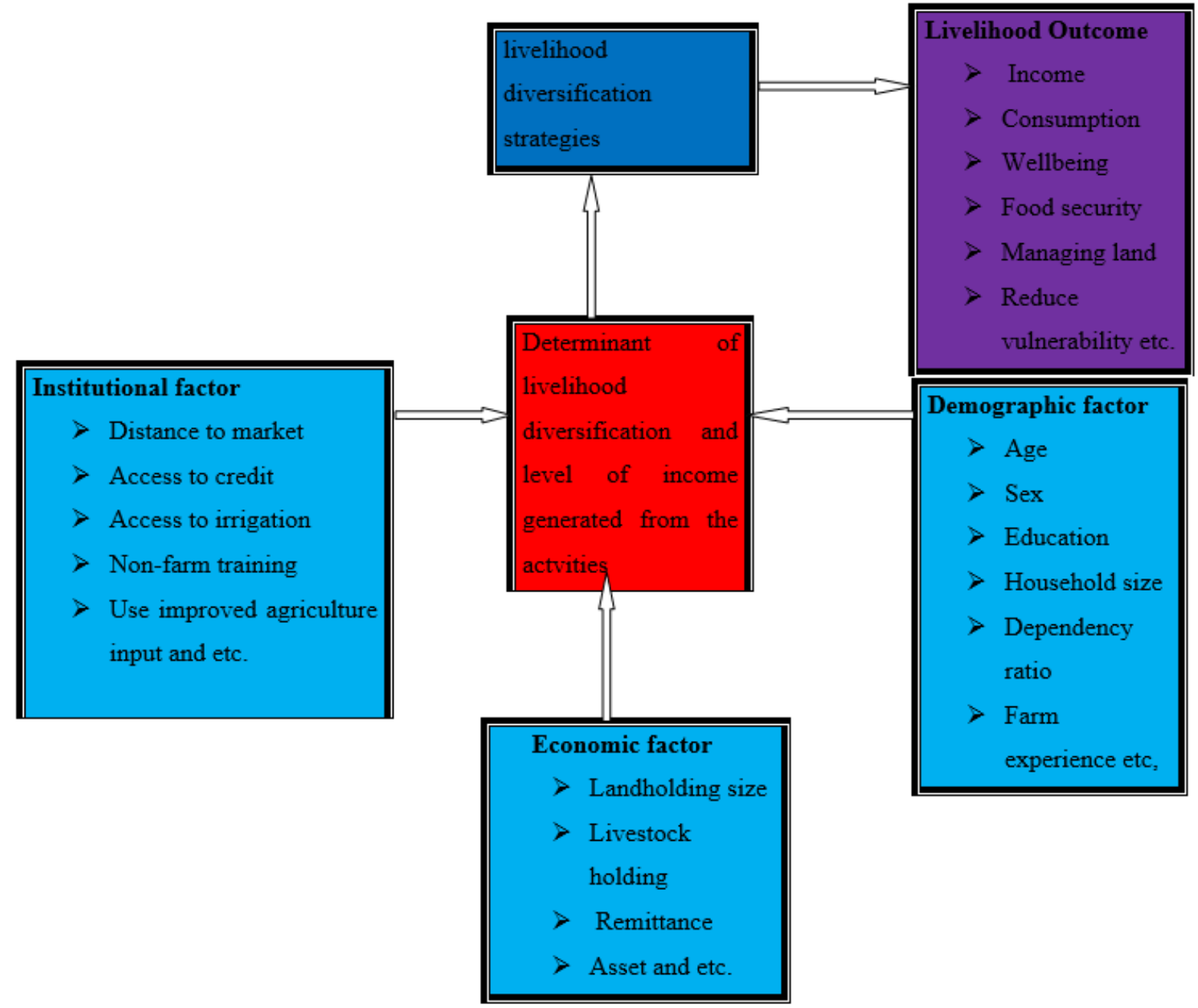

Figure1: Conceptual framework of the review

Source: Developed by the author based on available literature

\section{Conclusion and policy implication}

Agriculture is the backbone of Ethiopian economy; it contributes $79 \%$ of foreign earnings, employs $79 \%$ of the 
population and $34.1 \%$ to the GDP and is the major sources of raw material and capital for investment and market. Despite the economic dominance of agriculture in Ethiopia, the existing capacity of agriculture to attain food and livelihood security is tremendously declining from time to time due to diverse challenges and risks. For this reason Ethiopian government gives emphases and design policies and strategies to improve the livelihood of the rural population through agricultural development. However, the role of agricultural productivity in poverty reduction, improving livelihood and enhancing productivity outcomes cannot be over emphasized. As a result, Income diversification has been recognized by rural household as mechanisms to sustain the livelihood of the rural society and overcome dilemma associated to rural economy. For instance, the participation rate of rural household in off farm had been increasing from 55\% in 2004 to $75 \%$ in 2008 in Ethiopia; share of non-income was increasing from 16.1 in 1994 to 26.71 in 2009 . With this case, this review paper is aimed to compile the existing literature on impact of income diversification on outcome of rural livelihood, identifying the determinant participation of rural household in income diversification, and factors affecting level of income generated from the activities in the country.

Based on reviewing different researches output of livelihood strategies are better in diversified setting than single-handedly farming settings. Hence, its concluding that diversification into non/off-farm in addition to onfarm activities has positive impact on the rural farming households' outcome. Thus, efforts to improve the effect of income diversification on outcome of farmers need understanding and recognition of the constraints and opportunities of farmers' involvement in off/non farming activities.

Now, based on reviewing the result of previous study regarding to this topic, some basic future policy implications were developed: The review was found the positive impact of income diversification on the livelihood of outcome and identified the variables that affect participation of rural household in income diversification activities and level of income generated from the activities in Ethiopia. As a result, policy makers should give due emphasis to the aforementioned variables in the empirical review that determine participation of rural household in income diversification activities so as to improve the livelihood of smallholder farmers that responsible for rural development in Ethiopia. Some policy implications were also put in this paper as follows:

- In Ethiopia various agricultural policies has been implemented so as to improve livelihood of farmers through reducing poverty, achieving food security and welfare by increasing agricultural productivity. However, agricultural productivity could not realize what they are formulated under policies because they have paying attention only on agricultural development. Therefore, agricultural development policies should incorporate off/non-farming activities for realizing the enhancement of smallholder farmers' livelihood.

- There are a number of challenges hamper the involvement of rural households in income diversification strategies within rural areas. Therefore, rural development actors should abolish the restriction that barriers smallholder farmers engaging in income diversification activities and also should integrate awareness creation on substance of diversifying livelihood strategies.

- In overall as reviewed from various literatures income diversification activities are playing a vital role in the livelihood of rural population in Ethiopia. Thus, Development planners should take into account the livelihood portfolios of rural households in order to enhance rural development through giving attention to expand nonfarm sectors in the rural area

\section{Reference}

[1] MOA (2019). Transforming Ethiopian Agriculture: Power Point Presentation, Briefing for Agricultural Scholar Consultative Forum, April 2019, Addis Ababa

[2] WFP (2020). Ethiopia country strategic plan (2020-2025)

[3] Abebe, G.G. (2014). Off-Farm Income and Technical Efficiency of Smallholder Farmers in Ethiopia Year of publication: 2014 No: 862 ISSN 1401-4084

[4] Teshome, A., de Graaff, J. and Kessler, A. (2016). Investments in land management in the north-western highlands of Ethiopia: the role of social capital. Land Use Policy 57:215-228

[5] Tegegne, D. (2020). Determinants of Smallholder Farmers' Livelihood Strategies in Wogera District of Ethiopia

[6] CSA (Central Statistical Agency). (2014). Report on area and production of major crops (Private Peasant Holdings, Meher Season): agricultural sample survey 2015/2016 (2008 E.C.), vol I, Addis Ababa

[7] Bezu S, and Holden S (2014) Are rural youth in Ethiopia abandoning agriculture? World Dev 64:259-272

[8] Beyene, AD. (2010). Determinants of off-farm participation decision of farm households in Ethiopia Article in Agrekon· May 2010 DOI: 10.1080/03031853.2008.9523794

[9] Headey D, Dereje M, Taffesse AS (2014) Land constraints and agricultural intensification in Ethiopia: a village-level analysis of high-potential areas. Food Policy 48:129-141

[10] Beneberu A.W, Admassu, T.H. and Sarah M.N. (2019). Determinants of farm livelihoods of smallholder farmers in Yayu biosphere reserve, SW Ethiopia: a gender disaggregated analysis 
[11] (IPCC) Intergovernmental Panel on Climate Change, (2014). Climate Change 2014: Impacts, Adaptation, and Vulnerability. Chapter 20.

[12] IFAD. 2010. International Fund for Agricultural Development and Climate Change Strategy. Rome, Italy.

[13] Maplecroft, (2015). Climate change vulnerability index 2015 Maplecroft's Climate Change and Environmental Risk Atlas (CCERA) Maplecroft, UK

[14] Latest Global Hunger Index Results". Global Hunger Index. Retrieved 12 November 2018

[15] Yuya, B. A. and Daba, N. A. (2018) "Rural Households Livelihood Strategies and its Impact on Livelihood Outcomes: The Case of Eastern Oromia, Ethiopia", AGRIS on-line Papers in Economics and Informatics, Vol. 10, No. 2, pp. 93-103. ISSN 1804-1930. DOI 10.7160/aol.2018.100209.

[16] Getachew, D. (2020). Agricultural and Rural Transformation in Ethiopia Obstacles, Triggers and Reform Considerations Policy Working Paper 01/2020 Addis Ababa, Ethiopia

[17] Woldenhanna, T., and Oskam, A. (2001). Income diversification and entry barriers: evidence from the Tigray region of northern Ethiopia. Food Policy,26(4), 351-365.

[18] Haggblade, S., Hazell, P. and Reardon, T. (2010). The Rural Nonfarm Economy: Prospects for Growth and Poverty Reduction. World Development, 38(10):1429-1441

[19] Haggblade, S., P.B.R. Hazell and T. Reardon (eds) (2007) Transforming the Rural Nonfarm Economy: Opportunities and Threats in the Developing World. (1st edn). Baltimore: International Food Policy Research Institute.

[20] Barrett, C., Reardon, T. \& Webb, P. (2001). Non-Farm Income Diversification and Household Livelihood Strategies in Rural Africa: Concepts, Dynamics and Policy Implication. Food Policy, 26(4), 315-331. http://dx.doi.org/10.1016/S03069192(01)00014-8.

[21] Babatunde, R.O. and Qaim, M. (2009). "Patterns of Income Diversification in Rural Nigeria: Determinants and Impacts”. Quarterly Journal of International Agriculture, 48(4), 305-320.

[22] Bezu S, Barrett CB, Holden ST (2012) Does the nonfarm economy offer pathways for upward mobility? Evidence from a panel data study in Ethiopia. World Dev 40(8):1634-1646

[23] Amsalu, B., Kindie, G., Belay, K. and Chaurasia, S. P. R. (2014). The role of rural labor market in reducing poverty in Western Ethiopia. Journal of Development and Agricultural Economics, Vol. 6, No.7, pp. 299308. DOI 10.5897/JDAE2013.0518.

[24] Sisay, A.W. (2010). Participation into Off-farm Activities in Rural Ethiopia: who earns more? MA Thesis, Erasmus University, Hague, Netherland.

[25] Geremew, W.K, Sangho, K and Francisco, P.F.Jr. (2017). Determinant factors of livelihood diversification: Evidence from Ethiopia; Cogent Social Sciences https://doi.org/10.1080/23311886.2017.1369490

[26] Misganaw, T.A., Atsushi, T., Enyew, A., Nigussie, H. , Zerihun. N., Zemen. A., Asres, E., Dessalegn, M. and Daregot, B. (2019). Exploring Drivers of Livelihood Diversification and Its Effect on Adoption of Sustainable Land Management Practices in the Upper Blue Nile Basin, Ethiopia

[27] Bereket, Z. and Zenebe, G. (2011). Effect of Nonfarm Income on Household Food Security in Eastern Tigrai, Ethiopia: An Entitlement Approach; Food Science and Quality Management ISSN 2224-6088 (Paper) ISSN 2225-0557 (Online) Vol 1

[28] Ahmed, B. (2016). What factors contribute to the income differential? ISSN(e): 2223-1331/ISSN(p) Evidence from East Hararghe, Oromia, Ethiopia;2226-5724.

[29] Musa, H.A. and Kumilachew,A.M. (2018).Impact of off-farm activities on technical efficiency: evidence from maize producers of eastern Ethiopia, Agricultural and Food Economics, DOI 10.1186/s40100-0180098-0

[30] Beyene, F. and Muche. (2010). Determinants of food security among rural households of central Ethiopia: An empirical analysis. Q. J. Int. Agric., 49, 299318.

[31] Yenesew, S. Y., Eric, N. O. and Fekadu, B. (2015). Determinants of livelihood diversification strategies: The case of smallholder rural farm households in Debre Elias Woreda, East Gojjam Zone, Ethiopia. African Journal of Agricultural Research, 10, 1998-2013. doi: 10.5897/AJAR2014.9192

[32] Amare, D. and Belaineh, L. (2013) "Determinants of income diversification among rural households: The case of smallholder farmers in Fedis district, Eastern Hararghe zone, Ethiopia", Journal of Development and Agricultural Economics, Vol. 5, No. 3, pp. 120-128. DOI 10.5897/JDAE12.104

[33] Ambachew, M. D., \& Ermiyas, A. (2016). Determinants of Rural Household Livelihood Diversification Strategy in South Gondar Zone, Ethiopia. Journal of Agricultural Economics, Extension and Rural Development, 4(8), 548-560.

[34] Dereje, T.R. (2016).Rural Livelihood Strategies and Household Food Security: The Case of Farmers Around Derba Cement Factory, Sululta Woreda, Oromia Regional State

[35] Yizengaw, B. (2014). Determinants of Household Income Diversification and Its Effect on Food Security Status in Rural Ethiopia: Evidence from Ethiopia Longitudinal Rural Household Survey, Addis Ababa University, Addis Ababa, Ethiopia 
[36] Bekele, G.E, Deyi, Zh., Kidane, A. A. and Dessalegn, A.S.(2019).Household Income Diversification and Food Security: Evidence from Rural and Semi-Urban Areas in Ethiopia

[37] Ali, M. and Peerlings, J. (2012). "Farm Households and Non-Farm Activities in Ethiopia: Does Clustering influence Entry and Exit?" Agricultural Economics, 43(3), 253-266. http://dx.doi.org/10.1111/j.15740862.2012.00580.x.

[38] Fami, A. and Adinan, A. (2020). Impact of Non-farm Activities on Wellbeing of Rural Household, the Case of Kersa District, Eastern Hararghe Zone, Ethiopia. Humanities and Social Sciences. Vol. 8, No. 6, 2020, pp. 182-190. doi: 10.11648/j.hss.20200806.13

[39] Sharp, K., Devereux, S. and Amare, Y. (2003). Destitution in Ethiopia's north eastern highlands (Amhara National Regional State). Sussex, UK: Institute of Development Studies at the University of Sussex.

[40] Reardon, T. (1998). Rural Non-Farm Income in Developing Countries ', No. T.S.O.F.A. Agriculture (ed.).

[41] Weldegebriel, Z.B., Folloni, G. \& Prowse, M. (2015). The Determinants of Non-Farm Income Diversification in Rural Ethiopia, Journal of Poverty Alleviation and International Development, 6(1)

[42] Asfaw, A. (2018). Review on determinants of sustainable rural livelihood diversification of smallholder farmers in Ethiopia. International Journal of Advanced Research 6(2):251-259.

[43] Wondim, A.K. (2019). Determinants and challenges of rural livelihood diversification in Ethiopia: Qualitative review, Journal of Agricultural Extension and Rural Development

[44] Chambers, R. and Conway, G. R. (1992). Sustainable rural livelihoods: practical concepts for 21 st century. Institute of Development Studies Discussion Papers, 296, Cambridge

[45] DFID (2000). Sustainable Rural Livelihoods Guidance Sheet, London, UK

[46] Ellis, F., and Allison, E. (2004). Livelihood diversification and natural resource access: Overseas Development Group Working paper 9. University of East Anglia UK.

[47] Farrington,J., T.Ramsut, J.walker,(2002).sustainable livelihood Approach in urban areas: general lessons, with Illustration from Indian cases,ODI,London,UK

[48] Bezemer,D.J and Lerman,Z.(2002). Rural livelihood in Armenia: the center for Agricultural Economic research, The Department for Agricultural economics \& management Discussion Paper No,4.03

[49] Kollmair \& Gamper (2002).Input paper for the Integrated Training Course of NCCR North-South Aeschiried, Swifter land (9-20,Sep,2002)

[50] DFID (1999). Sustainable Rural Livelihoods Guidance Sheet, London, UK

[51] Scoones, I. (1998). Sustainable rural livelihoods: A Framework for Analysis ${ }^{e e}$, IDS working paper 72.

[52] Ellis, F. (2000). The determinants of rural livelihood diversifcation in developing countries. J Agric Econ.51(2):289-302

[53] Yizengaw, S. Y., Okoyo, E. N. and Fekadu, B. (2015) "Determinants of livelihood diversification strategies, The case of smallholder rural farm households in Debre Elias Woreda, East Gojjam Zone, Ethiopia", African Journal of Agricultural Research, Vol. 10, No. 19, pp. 1998-2013. ISSN 1991-637X. DOI 10.5897/AJAR2014.9192.

[54] Melese, A.T., Getaneh, M.A. and Gemechu, S.O. (2018). Determinants of Rural Households Livelihood Diversification Strategies in Kuarit District, West Gojjam Zone of, Amhara Region, Ethiopia. International Journal of Economic Behavior and Organization. Vol. 6, No. 3, 2018, pp. 61-68. doi: 10.11648/j.ijebo.20180603.11

[55] Yishak, G. (2017). Rural Farm Households' Income Diversification: The Case of Wolaita Zone, Southern Ethiopia. Social Sciences. Vol. 6, No. 2, 2017, pp. 45-56. doi: 10.11648/j.ss.20170602.12

[56] Mesfin, H.T. (2020). Determinants of Income Diversification among Rural Farm Household in Soddo District, Gurage Zone of Southern Ethiopia. Developing Country Study. ISSN 2224-607X (Paper) ISSN 2225-0565 (Online) Vol.10, No.10, 2020. DOI: 10.7176/DCS/10-10-02

[57] Reardon, T., J. Berdegué and G. Escobar (2001) 'Rural Nonfarm Employment and Incomes in Latin America: Overview and Policy Implications', World Development 29(3): 395-409.

[58] Tefera, T. L., Perret, S. and Kirsten, J. F. (2005). Diversity in Livelihoods and Farmers Strategies in the Hararghe Highlands, Eastern Ethiopia. International Journal of Agricultural Sustainability, 2, 133-146

[59] Van den berg, M. and Kumbi, G.E. (2006). Poverty and the Rural Nonfarm Economy in Oromia, Ethiopia. Agricultural Economics, 35, 469-475.

[60] Yisihake, E. and Dr. Anupama, U (2018). Determinants of Income Diversification and Its Share to Total Household Income in South, Nations, Nationalities and People Region, Ethiopia. JETIR, Volume 5, Issue 11 www.jetir.org (ISSN-2349-5162)

[61] Assefa, F. (2011). Determinants of rural household's participation in non-farm activities and its effect on income distribution: The case of Wonchi district in central Oromia, Haramaya University

[62] Abebe, T.G (2012). Farm Assets and Nonfarm Activities Characteristic and Determinants of Nonfarm Activities in Small Holder Farmers: The case of North East Ethiopia, Tehuledere District

[63] Demie, A and Zeray, N. (2015). Determinants of Participation in the Rural Nonfarm Economy in Eastern 
Ethiopia: Journal of Economics and Sustainable Development, ISSN 2222-1700 (Paper) ISSN 2222-2855 (Online) Vol.6, No.23, 2015

[64] Gebrehiwot, WG., Hyacinth, EI, \& Philip, OP. (2018). Determinants of livelihood diversification strategies in Eastern Tigray Region of Ethiopia

[65] Tafesse, A., Balta, A. and Weldeyohannes, D. (2015). Small Holder Farmers' Participation in Non-Farm Activities: Evidence from Humbo District, Southern Ethiopia. Journal of Poverty, Investment and Development, ISSN 2422-846X An International Peer-reviewed Journal, Vol.7

[66] Aababbo, Y. E. and Sawore, A.M. (2015). Assessing determinant factors of income diversification among rural farm households in Ethiopia: the case of Leemo and Anileemo Districts, Hadiya Zone, South Nation Nationalities People Region. International Journal of Science and Research, ISSN (Online): 2319-7064

[67] Bealu, T. (2018). Analysis of livelihood diversification practice to promote rural households' food security: The case of Hawassa Zuria District of Sidama Zone, Ethiopia; Journal of Development and Agricultural Economic, Vol. 11(1), pp. 1-8, January 2019 DOI: 10.5897/JDAE2018.0926

[68] Fami, A. Lemma, Z. and Daniel, B. (2021). Determinant of Rural Household Participation in Non-Farm and Level of Generated Household Income from the Activities: The Case of Haramaya Woreda, East Hararghe Zone, Ethiopia

[69] Mabiratu, D.K., Beneberu, A.W. and D. Prem, K.Dara. (2019). "Linkage between Income Diversification and Asset Ownership in Rural Households of Yayu Woreda And Hurumu Woreda, Oromia Regional State, Ethiopia." International Journal Of Research - Granthaalayah, 7(1), 56-72. Https://Doi.Org/10.5281/Zenodo.2550091

[70] Mohammed, A. \& Fentahun, T. (2020). Intensity of income diversification among small-holder farmers in Asayita Woreda, Afar Region, Ethiopia, Cogent Economics \& Finance, 8:1, 1759394, DOI: 10.1080/23322039.2020.1759394

[71] Tewele, H. (2012). Determinants of Rural Households' Off-farm Employment Participation and Income in Rural Tigray: Evidence from Endamokonni and Degua Tembien Woredas of Tigray Region, Ethiopia. The Master of Science In Economics

[72] Lemi, A.(2009). Determinants of Income Diversification In Rural Ethiopia: Evidence From Panel Data: Ethiopian Journal of Economics, 18(1). doi:10.4314/eje.v18i1.59930

[73] Demie, A and Zeray, N. (2015). Determinants of Participation in the Rural Nonfarm Economy in Eastern Ethiopia: Journal of Economics and Sustainable Development, ISSN 2222-1700 (Paper) ISSN 2222-2855 (Online) Vol.6, No.23, 2015

[74] Teshome, B. and Edriss, A.K. (2013), Determinants and Patterns of Income Diversification among Smallholder Farmers in Akaki District, Ethiopia. Journal of Research in Economics and International Finance (JREIF), 2(4): 68-78.

[75] Loison, S. A. (2015). 'Rural Livelihood Diversification in Sub-Saharan Africa: A Literature Review'. The Journal of Development Studies, 51(9): 1125-38. https://doi.org/10.1080/00220388.2015.1046445 